\title{
Wacquant, urban marginality, territorial stigmatization and social work
}

\author{
Ian Cummins University of Salford, UK
}

\begin{abstract}
Loic Wacquant is currently Professor of Sociology at the University of California, Berkeley. He has written extensively on issues related to urban poverty, race and the expansion of imprisonment. Wacquant is heavily influenced by the work of the late Pierre Bourdieu. Specifically, Wacquant employs Bourdieu's theoretical tools of analysis to provide a critique of contemporary neo-liberal social and penal policy. This article considers the potential applications of Wacquant's scholarship to contemporary social work practice. For the purposes of this analysis, Wacquant's work is divided into three broad areas: the analysis of neo-liberalism and precarious forms of employment, the development of the penal state and his critical approach to doxa. Bourdieu uses the term doxa to refer to those views or opinions that are taken for granted within any society. They thus create the limits of, or provide a strong framework for, political and policy debates. It is argued that Wacquant's theorisation provides an explanation of the forces that have led to the concentration of areas of poverty in the midst of relative affluence. In addition to facing long-standing problems of high unemployment, poor housing and a lack of social amenities, these areas - the banlieues in France, housing projects in the USA and estates in England - are stigmatized in public and media discourse. Wacquant's work can be used to challenge the development of a form of social work that places emphasis on bureaucratic managerialism. In addition, it should encourage social work as a profession to re-engage with criminal justice issues. Finally, the critical approach to doxa provides a model for social work to challenge the limitations of current debates.
\end{abstract}

KEYWORDS: Wacquant, social work, neo-liberalsim, urban marginality, territorial stigmatization

\section{Introduction}

Social work, as a profession is fundamentally concerned with notions of equality, citizenship and social justice. The IFSW (2014) definition of social work commits social workers to working alongside individuals, groups and communities to challenge injustice and discrimination. However, recent trends in social policy in England and Wales have had significant implications for the role of social work. It has become increasingly driven by prescribed procedures and focused on risk management. This trend can be seen across the UK, Australia and New Zealand and is evident in a number of areas of social work practice. Mental health services are a prime example. The reform of the Mental Health Act in 2007 in England and Wales led to the introductions of Community Treatment Orders. The legislation was almost a carbon copy of that introduced in Australia (Cummins, 2013). In addition wider social discourses have moved from a concern with the impact of structural inequalities to a moralistic discourse (Welshman, 2012) that sees poverty as resulting from perceived individual failings. In the UK context, as the state has withdrawn from a programme of social welfare provision, those systems that remain have become increasingly punitive (Crossley, 2015).
AOTEAROA

New Zealand SOCIAL WORK 28(2), 75-83.

CORRESPONDENCE TO: Ian Cummins I.D.Cummins@salford.ac.uk 
This shift is very apparent in the British context and has continued whatever the political complexion of recent governments. The Barr et al. (2015) study of the recently introduced system of work capability assessments for those in receipt of disability benefits highlights negative impacts on the mental health of those subject to this new regime. The authors argue that effects included an additional 590 suicides and nearly three quarters of a million more prescriptions for anti-depressants. The early achievements of the Blair government in reducing child poverty and investing in public services have been lost (Toynbee and Walker, 2011). Despite positive investments in services such as Sure Start, the Blair years also saw the return of a more judgemental discourse around the causes of poverty and appropriate policy responses (Butler and Drakeford, 2001).

The above tone was continued under the Coalition Government from 2010 onwards. In 2011, there was a series of riots that began in London and then spread across other urban areas. The punitive trend in social policy became more pronounced after these riots. The Troubled Families Agenda was the Government's social policy response. The policy itself has its origins in the New Labour Government's 2006 Respect Agenda which claimed to identify a group of chaotic families who were a drain on public services, including health, social services, education and the police. As Crossley (2015) notes, the Respect Agenda was, at least nominally, focused on multiple disadvantages such as low income and poor housing. In this new incarnation, troubled families are described as:

... households who: are involved in crime and anti-social behaviour, have children not in school, have an adult on out of work benefits and cause high costs to the public purse.

A clear rhetorical shift is evident. Levitas (2012) outlines the porous nature of these categories: a "family with troubles" quickly becomes a "troubled family". Beddoe (2015) notes, in her discussion of similar policy developments in New Zealand, that these shifts have taken place at a time of cuts and retrenchment in the welfare budget. They thus become part of an ideological discourse that justifies austerity. They help to create a poisonous public environment where the poorest members of society are demonised as "feckless scroungers".

The policy discussion outlined above provides a context for this article which is a consideration of some of the key themes in the work of the French sociologist Professor Loic Wacquant. It will be argued that his work provides critical insights that can be used both to analyse the context of contemporary social work and as the basis for a more engaged approach to practice. Wacquant (2008, 2009(a), 2009(b)) develops an analysis of neo-liberalism as an overtly political project. He examines the impact of the economic and social insecurity that is a key feature of neo-liberalism. It is proposed that, even before the current policies of austerity, there was a clear shift to more punitive forms of welfare provision.

Wacquant's work is specifically concerned with penal policy, particularly the expanded use of imprisonment and is largely focused on the USA, which now has the largest prison population in the world (Institute for Criminal Policy Research, 2016).

Wacquant also explores the mechanisms of modern - particularly urban - poverty. In this area, he examines the ways in which marginalized communities have become physically, spatially and economically cut off from wider society. With its focus on structural barriers to full citizenship, Wacquant's work provides a counter to the dominant narrative which pathologises poor people and impoverished communities. This article argues that this analysis resonates with some of the key traditional concerns of the social work profession. It can therefore act as a basis for social work practice that is much more community focused and 
orientated towards social justice approaches. This shift entails a rejection of procedural, bureaucratic and risk based models and rediscovery of the notion of dignity as a driver for the development of new forms of practice.

\section{Wacquant and the penal state}

The growth of social insecurity which has seen the removal of social protections for workers, an increase in short-term employment and more punitive attitudes, has been accompanied by the expansion of imprisonment (Wacquant $(2008,2009$ a and 2009b) For Wacquant, neo-liberalism has seen the development of a new form of statecraft. This has been variously termed the penal state or mass incarceration. The USA now holds over twenty-five per cent of the world's prisoners. The impact on the African-American community, in particular, has been devastating (Mauer, 2006; Clear, 2007; Drucker, 2011). Alexander (2012) argues that this has served to create a new 'caste' of marginalised, disenfranchised, young black men. Although the USA has led the way in the penal arms race, the trend is discernible in other jurisdictions. The standard way to measure imprisonment is per 100, 000 of the population. In England and Wales, the rate in 2000 was 124 per 100, 000, and in 2014 it was 149. In New Zealand, for the same dates, the rates were 148 and 190 respectively (Institute for Criminal Policy Research, 2016).

Garland (2001), Simon (2007), and Harcourt (2011) tend to analyse the punitive drive in terms of the culmination of a number of cultural shifts. Wacquant (2008) stands somewhat apart from these contemporary scholars in relation to the development of the penal state. He proposes that what he terms "prison fare" is an endogenous feature of neoliberal regimes: that the Police, Courts and Prisons are key political institutions that not only manage the inequality and marginality, but are also active in its production and maintenance. Wacquant's study of penal policy is interlinked with his work on race and urban marginality. The term "urban marginality" is used to convey the ways that significant groups of people are effectively locked out of access to the resources and mechanisms of modern citizenship such as decent education, health, social care and full-time permanent, well-paid, employment. Although his work has focused on the US, these trends can clearly be identified across other advanced economies. Savage's (2015) recent discussion of class provides a detailed analysis of these processes in the UK.

\section{Neo-liberalism and poverty}

Over the past thirty years neo-liberalism has become the dominant political ideology in Anglophone societies. Aside from its economic impact, neo-liberalism has crowded out other approaches in both the social and political spheres (Giroux, 2011). In the area of social provision, the "underclass" discourse has been developed. Murray (1990) has been the leading theoretical proponent of these views. This is vitally significant in the context of social work - particularly social work with children and families. This work, as Featherstone, White \& Morris (2014) demonstrate, takes place with families who are living in poverty. The shift that has occurred is that living in poverty has almost come to be seen as an indicator of a lack of the capacity to parent. Slater (2012) argues that the underclass hypothesis inevitably constructs the poor in eugenicist terms. Sayer (2015) suggests that public attitudes towards the rich (particularly bankers) have hardened since the financial crash of 2007. He goes on to claim that, paradoxically, social attitudes have become even more critical of those at the other end of the social scale. In the UK, these changes manifest themselves most clearly in popular culture and tabloid media where the demonization of the poor is widespread (Tyler, 2008; Shildrick et. al, 2009; Sutton, 2009; Mooney, 2011; Jensen, 2014).

This process inevitably has an impact on social work, as the majority of practice takes place in poor areas or with marginalised individuals. Savage (2015) outlines the way 
that the UK and, by implication, other liberal economies are increasingly socially as well as economically segregated. Wilkins and Pickett (2010) demonstrate that this inequality has social and psychological as well as economic effects. Put simply, there are huge differences between the physical and mental health of the richest and poorest in society. These differences are starkest in the most unequal societies. More equal societies with progressive welfare and health systems mitigate these potentially adverse outcomes (Marmot, 2015).

From the late 1990s onwards, in the UK and across Europe, there has been an ongoing moral panic (Cohen, 2011) about the "ghettoization" of socially deprived urban areas. The term ghetto - in modern usage suggests an area of poor housing, poverty, substance misuse problems, high crime and gang violence. It is also has racist overtones. More recently in the UK, Governments of all political persuasions have been concerned with the issue of so-called "problem" or "sink" estates. In Drake and Cayton's (1993) classic study, the ghetto is described as a "black city within the white". Slater (2009) argues that the ghetto is a social and psychological space with its boundaries created by ethnicity. However, it is also a space that sustains social ties and generates community organisation.

In Wacquant's schema, there are significant structural and cultural differences between modern, urban, spatially concentrated poverty and the "ghetto" as understood in the above analysis. Accordingly he argues that the use of this term is not an accurate way of describing areas of urban povery in neo-libearl societies. This might appear a technical point but it is an important one. Wacquant proposes that social and community institutions are much more difficult to develop in contemporary environments. Previously strong civic institutions, ranging from political to social and from trade unions to sports and youth clubs, have either been lost or struggle to survive in the current precarious neo-liberal world. The lack of social, educational and cultural amenities adds to the experience of poverty. The involvement of the social state in organised welfare provision has been reduced, or in some areas has virtually disappeared. In such areas, policing and broader law and order systems are the most common way that the state manifests itself.

Wacquant (2010) argues that the underclass discourse not only corrodes the sense of self of residents but also makes it more difficult to develop and maintain broader social relationships. These relationships are vital as they can act as supports for individuals and provide a buffer against the pressure that the insecure nature of much modern employment creates. It is very important to note that Wacquant is not suggesting that such social systems do not exist. For example, Body and Soul (2000), examines the experience of young black men who use a gym in Chicago and considers the function of these informal structures in some detail. In a similar vein, McKenzie's (2015) portrait of life on a Nottingham estate - Getting By focuses not only on the economic and social pressures facing the residents but also the ways in which they overcome them.

Wacquant uses Goffman (1963) and Bourdieu (1999) as the starting point for his analysis of the development and impact of stigma. Goffmnan (1963, p.3) describes stigma as an "attribute that is deeply disturbing", and goes on to suggest that this attribute reduces the holder "from a whole and usual to a discounted one". There has been a very significant expansion in the use of stigma as an analytical tool. It is widely applied to analysis of personal circumstances in relation to physical disability, race, sexual orientation and mental health. Stigma can thus be seen as characteristic of groups or individuals who are deemed to be, in some way, outside the norms of the broader society. The processes that result in the construction of categories, what Foucault (1982) termed "dividing practices", which are also linked to sets of stereotypical beliefs. As Link and Phelan (2001) argue, 
stigmatization is inevitably entwined with social, economic and political power and capital. The labelling of individuals and the construction of stereotypes is followed by disapproval, rejection and discrimination.

McKenzie (2015) applies this analytical lens to the day to day lives of residents on an estate in Nottingham. She illustrates the way that the wider society stigmatises individuals, families and communities simply because they live in the St Ann's area of Nottingham. Being a resident meant that one had to negotiate a series of deeply entrenched wider social attitudes. As she demonstrates, there is also strength and resilience in the community - capacities that are often ignored or pathologised outside of it. This is an example of what Wacquant (2007) terms "territorial stigmatization" - the processes whereby areas are characterized by:

... forms of poverty that are neither residual, nor cyclical or transitional, but inscribed in the future of contemporary societies insofar as they are fed by the ongoing fragmentation of the wage labour relationship, the functional disconnection of dispossessed neighbourhoods from the national and global economies, and the reconfiguration of the welfare state in the polarizing city. (pp. 66-67).

Wider society does not focus on structural causes and features of poverty. It reconfigures them in the individualistic language of neo-liberalism - choice, lifestyle and personal responsibility. Thus, the areas themselves come to represent moral decay or failure. The stigma attached to such areas is incredibly powerful. Wacquant produces a theoretical schema which argues that the new forms of insecurity that neo-liberalism has produced lead to a new form of spatially concentrated urban poverty. The impacts of these developments affect both individuals and broader communities. The huge increase in imprisonment is an example of these dual effects. The sanction of imprisonment clearly has implications for the lives of individuals but also for already marginalised communities. These effects long outlast the sentence of imprisonment itself.

Wacquant's work has clearly been heavily influenced by that of his intellectual mentor, Pierre Bourdieu. Accordingly a number of the academic criticisms of Bourdieu have also been raised in relation to Wacquant. Measor (2013) suggests that Wacquant fails to engage with two vitally important areas; gender and resistance. Adkins and Skeggs (2004) also contend that he sidesteps issues of gender. Skeggs (2004) argues that in The Weight of the World (1999), Bourdieu portrayed the working class in terms that echoed the underclass discourse it set out to challenge. Measor (2013)) argues that Wacquant portrays the poor as "as a deprived people flattened by circumstances that fix them in place" (p. 135). In defence of Wacquant, the fact that the majority of his work explores the penal system means that a focus on the experience of men is inevitable to a degree. As such, the intent it is not necessarily to ignore the issue of gender, which is clearly of vital importance for social work. Further, Wacquant does not argue that the position of the stigmatized poor is completely determined, merely that it is increasingly difficult to escape under a neo-liberal state regime.

\section{Using Wacquant to inform social work practice}

There are three key areas where Wacquant's work is of particular relevance for social workers in contemporary Britain and comparable jurisdictions. I would identify these as the analysis of neo-liberalism and precarious forms of employment, the development of the penal state and his critical approach to doxa. As outlined below social work as a profession has a series of doxa which need to be interrogated. Wacquant's analysis of the development of the precariat - the weakening of collectively bargaining, the stripping away of employment protection and 
rights, "flexible" working, the reduction of real wages, zero hours contracts and the general expansion of the private sector - is connected with changes in the provision of public services over the past thirty years. These trends are clearly visible in relation to social welfare services and are associated with the development of social work practice that is increasingly focused on risk management, audit and bureaucratic responses. This results in the corrosion and marginalization of practice skills that focus on personal relationship building (Cummins, 2013 Kemshall, 2010; Warner, 2013; Webb, 2006). Tension between the expressed professional values of social work and the practice environment is increasingly evident.

In the broader context social work has found itself responding to an agenda of risk and risk management. This has seen a shift towards procedurally driven approaches to practice whereby a riskaverse audit culture that undermines professional autonomy is created. These trends are apparent in child protection, mental health and social work with adults. Such developments have led to a buildup of frustration among practitioners who see their professional autonomy restricted and undermined by a strait jacket of bureaucracy. Broadhurst et. al (2010) highlight the impact of these issues in the area of child protection social work. Similar themes are identified by Morriss (2016) in her discussion of mental health social workers' efforts to maintain a professional social work identity. At the same time, as outlined above, social and political discourse has created an atmosphere where concerns about poverty have become concerns about the alleged moral failings of the poor. This inevitably has implications for social work.

Social practitioners are trying to balance the key values of social justice with a practice environment that seems at odds with these beliefs (Featherstone et al, 2014; Garrett, 2014; Webber et al, 2014). In addition, social work has increasingly found itself responding to an agenda that recasts the problems of poverty and social deprivation as individual lifestyle choice (Casey, 2016). In this area, Wacquant, following on from Bourdieu, provides a clear theoretical framework to explain and challenge these developments. Wacquant's analysis of neo-liberalism as a distinct political project that brings with it a new form of statecraft provides a starting point for a social work practice response to increasing inequality in modern societies. His work focuses on the developing structures of inequality. In this analysis, inequalities are not simply economic, they are spatial and psychological. His theorisation provides a way of exploring the pressures and fissures within urban marginalised communities. This approach recognises that there are community groups and activists working to combat these issues, while identifying the structural barriers that these efforts are confronted with.

As Garrett (2013) argues social work's role has been more complex than is often allowed for. There is a danger that, in challenging the moves towards a functionalist, rationalist approach, a radical emancipatory golden age of social work practice is imagined. Social work has always been involved in the management of marginalised communities or individuals. Within these very broad parameters, individual workers and groups of workers have been able to carve out a creative space to work in ways that challenge prevailing trends or systems. Neo-liberal governmentality has significantly reduced these creative opportunities. This is a source of real professional frustration (Parton, 2014; Whittaker et al, 2015). Bourdieu (1999) outlined a schema that places the functions of the State into two broad categories - the Left Hand and the Right Hand. On the Right sit functions such as the Courts, Prisons and the Police. On the Left, the provision of welfare services in their broadest sense, such as education and health. Social work has the potential to be placed at either of these poles. The argument here is that increasingly, 
under neo-liberal modes of governance, social work has come to be constructed in disciplinary terms.

As with Bourdieu's work, Wacquant is seeking to expose and challenge the key theoretical assumptions of neo-liberalism. This approach can be used to critically explore the origins and use of terms that constitute doxa. Garrett's (2015) analysis of welfare dependency is an excellent example of this process of interrogation. He demonstrates the way that such terms develop and frame debates. As he shows, the linkage of welfare with dependency has moved from the work of academics such as Murray (1990) and Meade (1992) to the policy realm of Government. In current social work practice, examples of doxa might include resilience, disguised compliance and personalization. Whatever the original emergence and purpose of such terms, they come to be used in very uncritical and instrumental ways. Resilience is a particularly interesting example as it is now also being used in the assessment of social workers and students. Students and newly qualified practitioners in particular are being asked to demonstrate that they are 'resilient' in the face of increasing pressures. The difficulties of poorly resourced organisations are thus reconfigured as problems of individuals and done so in an offensively moralistic tone.

Wacquant's scholarship brings together sociological, criminological and political theory in challenging and stimulating ways. Consideration of his work on the penal system may provide a basis for social work to reconnect with the issue of criminal justice. At the core of his analysis is a concern with the development of the state under neo-liberalism. His theorisation of the development of the penal state - the expansion of the use of imprisonment over the past thirty years - is unique as he sees it as endogenous to the neo-liberal project. Simon (2014) has compared mass incarceration to a biblical flood which is now beginning to recede. Ironically, one of the reasons for this is the recognition that its costs are a drain on the public purse. England and Wales is the European jurisdiction that has most closely followed this route. It is a statement of the obvious, but one worth repeating, that prisoners come from the most marginalised communities. For example in England, The Cortson Inquiry (2008) into the experiences of women in prison highlighted the very high levels of mental health issues amongst this group - $51 \%$ had a severe and enduring mental illness and $37 \%$ had attempted suicide at some point in their lives. I have argued (Cummins, 2016) that social work, as a profession, has largely overlooked the damage that mass incarceration has done to individuals, families and communities. One reason for social workers to engage with the work of Wacquant is to redress this balance.

Taylor (2003) argues that common sense or more widely held views are often not outlined in theoretical or abstract form. The importance of images, stories and popular myths should not be underestimated. This has particular resonance in the area of social and welfare policy. The tabloid media, alongside populist TV documentaries, have had a pivotal role in framing a discourse that welfare is a state subsidy for feckless scroungers. As Welshman's (2013) analysis demonstrates, this discourse has been in existence for over two hundred years and seems to be recast in a new form every twenty or thirty years. However, it appears particularly virulent in its current iteration. This is an important issue for social work. As a profession, it is committed to social justice so should therefore challenge this discrimination and classism. In addition, these attitudes are actually at the root of many policy developments which have seen the marginalisation of social work based on relational ideas. The strength of Wacquant's work is the analysis of the structural, economic and spatial inequalities that social workers need to challenge if they are 
practice in a way that is consistent with the IFSW (2104) definition of the profession. Social work needs to reinvigorate a professional culture that sees the poor, marginalised and excluded not as sites of risk but as fellow citizens. Rediscovering dignity and the work of Wacquant can be a starting point for this process.

\section{References}

Adkins, L., \& Skeggs, B. (Eds.). Feminism After Bourdieu. Oxford: Blackwell.

Alexander, M. (2012). The New Jim Crow; Mass Incarceration in the Age of Colorblindness. New York: New Press.

Barr, B., Taylor-Robinson, D., Stuckler, D. et al. (2015). "First do no harm" are disability assessments associated with adverse trends in mental health? A longitudinal study. J Epidemiol Community Health doi:10.1136/jech2015-206209.

Beddoe, L. (2014). Feral families, troubled families; the spectre of the underclass in New Zealand. NZ Sociology, 29(3), 51-68.

Bourdieu, P. (1986). The forms of capital. In J. Richardson (Ed.) Handbook of Theory and Research for the Sociology of Education. New York: Greenwood, pp.241-258.

Bourdieu, P. (1998). The Left Hand and the Right Hand of the State, in P. Bourdieu Acts of Resistance, pp. 1-10. Cambridge: Polity Press.

Bourdieu et al. (1999). The Weight of the World Social Suffering in Contemporary Society. Oxford, UK: Polity Press.

Broadhurst, K., Hall, C., Wastell, D., White, S., \& Pithouse, A. (2010). Risk, Instrumentalism and the Humane Project in Social Work: Identifying the Informal Logics of Risk Management in Children's Statutory Services. British Journal of Social Work, pp. 1-19.

Casey, L. (2016). Lessons from Rotherham and my work with troubled families in Rethinking Children's Services Fit for the Future? http://www.catch-22.org.uk/wpcontent/uploads/2016/04/Rethinking-Childrens-ServicesFINAL.pdf

Clear, T. (2009). Imprisoning Communities: How Mass Incarceration Makes Disadvantaged Neighborhoods Worse. New York: OUP.

Corston, J. (2007). The Corston Report. www.justice.gov. uk http://www.justice.gov.uk/publications/docs/corstonreport-march-2007.pdf

Crossley, S. (2015). 'Realising the (troubled) family', 'crafting the neoliberal state'. Families, Relationships and Societies. http://dx.doi.org/10.1332/ 204674315X14326465757666

Cummins, I. (2013). Using Simon's Governing through crime to explore the development of mental health policy in England and Wales since 1983. Journal of Social Welfare and Family Law, 34(3), 325-337.

Cummins, I. (2016). Mental Health and the Criminal Justice System: A social work perspective. St Albans: Critical Publishing.
Drake, C., \& Cayton, H. (1993) (4th Ed). Black Metropolis: A Study of Negro Life in a Northern City. Chicago: University of Chicago Press.

Drucker, E. (2011). A Plagues of Prisons; The Epidemiology of Mass Incarceration in America. New York: New Press.

Featherstone, B., White, S., \& Morris, K. (2014). Reimagining child protection: Towards humane social work with families. Bristol: Policy Press.

Foucault, M. (1982). The Subject and Power in Michel Foucault: Beyond Structuralism and Hermeneutics by Hubert L. Dreyfus \& Paul Rabinow. Brighton: Harvester Press.

Garrett, P. (2013). Social Work and Social Theory Making Connections. Bristol: Policy Press.

Garrett, PM (2014). Re-enchanting social work? The emerging 'spirit 'of social work in an age of economic crisis. British Journal of Social Work, 44(3), pp.503-521.

Garrett, P. (2015). Words matter: deconstructing 'welfare dependency' in the UK. Critical and Radical Social Work, $3(3)$, pp. 389-40.

Giroux, H. (2011). Neoliberalism and the death of the social state: remembering Walter Benjamin's Angel of History Social Identities: Journal for the Study of Race, Nation and Culture, 17(4), 2011.

Goffman, E. (1963). Stigma: Notes on the Management of Spoiled Identities New York. NY: Simon and Schuster.

Harcourt, B. (2011). The Illusion of Free Markets: Punishment and the Myth of Natural Order. Cambridge, Mass Harvard University Press.

IFSW (2014) http://ifsw.org/get-involved/global-definition-ofsocial-work

Institute for Criminal Policy Reserach (2016), World prison brief. United Kindom: England and Wales. Retrieved from http://www.prisonstudies.org/country/ united-kingdom-england-wales

Jensen, T. (2014). Welfare, common sense, poverty porn and doxosophy, Sociological Research Online, 19(3). http://www.socresonline.org.uk/19/3/3.html

Kemshall, H. (2010). Risk Rationalities in Contemporary Social Work Policy and Practice. British Journal of Social Work, 4O(4), pp 1247-1262.

Levitas, R. (2012). There may be 'trouble' ahead: what we know about those 120,000 'troubled' families. Policy Response Series No. 3 - Poverty and Social Exclusion in the UK. http://www.poverty.ac.uk/policy-responseworking-papers-families-social-policy-life-chanceschildren-parenting-uk-government

Marmot, M. (2015). The Health Gap: The Challenge of an Unequal World. London: Bloomsbury.

Mauer, M. (2006). The Race to Incarcerate. New York: New Press.

Mckenzie, L. (2015). Getting By Estates, class and culture in austerity. Britain, Bristol: Policy Press.

Measor, L. (2013). Loic Wacquant, gender and cultures of resistance. In P. Squires, \& J. Lea (Eds.), Criminalisation and advanced marginality; Critically exploring the work of Loic Wacquant (pp. 129-151). Bristol: Policy Press.

Meade, L. (1992). The New Politics Of Poverty: The Nonworking Poor In America. New York: Basic Books. 
Murray, C. (1990). The Emerging British Underclass (Choice in Welfare). London: IE.

Mooney, G. (2011). Stigmatizing Poverty? "The Broken Society" and reflections on anti-welfarism in the UK Today. Oxford: Oxfam.

Morriss, L. (2016). Being Seconded to a Mental Health Trust: The (In) Visibility of Mental Health Social Work. British Journal of Social Work. pp 1-17.

Parton, N. (2014). Social Work, Child Protection and Politics: Some Critical and Constructive Reflections. British Journal of Social Work, 44(7), pp.2042-2056.

Savage, M. (2015). Social Class in the 21st Century (Pelican Introduction). London: Pelican.

Sayer, A. (2015). Why We Can't Afford the Rich. Bristol: Policy Press

Shildrick, T., Blackburn S., \& MacDonald, R. (2009). Young people, class and place. Journal of Youth Studies, 12(5), pp.457-465.

Simon, J. (2007). Governing Through Crime How the War on Crime Transformed American Democracy and Created a Culture of Fear. Oxford: OUP.

Simon, J. (2014). Mass Incarceration on Trial. NewYork: New Press.

Skeggs, B. (2004). Exchange, value and affect: Bourdieu and 'the self'. The Sociological Review. 52(Supplement s2).

Slater, T. (2009) 'Ghettos' and 'Anti-urbanism'. Entries in R. Kitchin and N. Thrift (Eds.). The International Encyclopaedia of Human Geography. London: Elsevier.

Slater, T. (2012). The Myth of "Broken Britain": Welfare Reform and the Production of Ignorance. Antipode 0, pp. 1-22.

Standing, G. (2014). The Precariat: The New Dangerous Class. London: Bloomsbury.

Stedman-Jones, G. (2013). Outcast London: A study in the relationship between classes in Victorian society. London: Verso.

Sutton, L. (2009). They'd only call you a scally if you are poor: the importance of socio-economic status on children's identities. Children's Geographies. 7(3), 277-290.

Taylor, C. (2003). Modern Social Imaginaries. Durham NC: Duke University Press.

Tyler, I. (2008). Chav Mum, chav scum class disgust in contemporary Britain. Feminist Media Studies, 8(1) pp 17-34.

Tyler, I. (2013). Revolting Subjects Social Abjection and Resistance in Neoliberal Britain. London: Zed Books.

Wacquant, L. (2000). Body \& Soul: Notebooks of an Apprentice Boxer. Oxford: OUP.

Wacquant, L. (2007). Territorial Stigmatization in the Age of Advanced Marginality." Thesis Eleven, 91, 66-77.

Wacquant, L. (2008). Urban Outcasts: A Comparative Sociology of Advanced Marginality. Cambridge: Polity Press.

Wacquant, L. (2008). Ghettos and Anti-Ghettos: An Anatomy of the New Urban Poverty. Thesis Eleven, 94, 113-118.

Wacquant, L. (2009). Prisons of Poverty. Minneapolis: UM Press.

Wacquant, L. (2009). Punishing the Poor: The Neoliberal Government of Social Insecurity. Durham: Duke University Press.
Wacquant, L. (2009). "The Body, the Ghetto and the Penal State." Qualitative Sociology, 32(1), 101-129.

Warner, J. (2013). Social work, class politics and risk in the moral panic over Baby P. Health, Risk \& Society, 15(3), pp 217-233.

Webb, S. (2006). Social Work in a Risk Society: Social and Political Perspectives. London: Palgrave Macmillan.

Webber, M., Reidy, H., Ansari, D., Stevens, M., \& Morris, D. (2014). Enhancing social networks: a qualitative study of health and social care practice in UK mental health services. Health and Social Care in the Community. pp 1-10.

Welshman, J. (2013). (2nd edition). Underclass: A History of the Excluded Since 1880. Bloomsbury: London.

Wilkinson, R., \& Pickett, K. (2010). The Spirit Level: Why More Equal Societies Almost Always Do Better. London: Penguin. 